\title{
Trends in the valuation of injury involving the face: an analysis on trial in Rio Grande do Sul, Brazil
}

\section{Tendências na valoração do dano corporal envolvendo a face: uma análise em julgados no Rio Grande do Sul, Brasil}

\author{
Gabriela Cauduro da ROSA ${ }^{1,2}$ iD 0000-0003-2845-6926 \\ Rosane Pérez BALDASSO ${ }^{1,2}$ iD 0000-0002-1889-1767 \\ Mário Marques FERNANDES ${ }^{1,2}$ iD 0000-0002-7063-475X \\ Fábio DELWING ${ }^{3}$ iD 0000-0002-9003-2350 \\ Rogério Nogueira de OLIVEIRA ${ }^{1}$ (iD) 0000-0003-0990-4834
}

\section{ABSTRACT}

Introduction: Facial injuries may change, considerably, people's quality of life. To measure the damage, the assessment of the bodily harm is required. Objective: To analyze jurisprudential characteristics involving the valuation of the damage related to facial trauma, highlighting trends. Methods: It was analyzed secondary data, which are public domain, of the precedents of the Court of Justice of Rio Grande do Sul State from 2008 to 2016. The sample consisted of 43 lawsuits in cases related to traffic accidents, falls or physical aggression that affected the face. Results: It was found that $86 \%$ of authors and defendants of the lawsuits analyzed are male. In $62.7 \%$ of cases physical aggression was the form of trauma that caused more injuries and the most common damage was dental fractures with $53.49 \%$. The monetary restitution for moral damages ranged from $R \$ 1,500.00$ to $R \$ 20,340.00$, and for aesthetic damage ranged from $R \$ 2,000.00$ to $R \$ 20,000.00$. Conclusion: The analyzed jurisprudence involving facial trauma allows us to verify the trend of need and value of the dentist expert to quantify damage involving the maxillofacial complex.

Indexing terms: Aesthetic. Forensic dentistry. Legislation \& jurisprudence.

\section{RESUMO}

Introdução: Lesões na região facial podem alterar a qualidade de vida de um indivíduo consideravelmente. Para mensurar esse prejuízo, é necessária a valoração do dano corporal. Objetivo: Analisar as características de jurisprudências que envolveram a valoração do dano ocasionado por trauma facial, destacando as tendências observadas. Métodos: Foram analisados dados secundários, os quais são de domínio público, de jurisprudências do Tribunal de Justiça do Rio Grande do Sul no período de 2008 a 2016. A amostra foi constituída por 43 acórdãos de processos relacionados a acidentes de trânsito, quedas ou agressões que atingiram a face. Resultados: Verificou-se que $86 \%$ dos autores e dos réus das jurisprudências são do sexo masculino. Em 62,7\% dos processos a agressão física foi a forma de trauma mais frequente e a consequência do dano foi fratura dentária com 53,49\%. Os valores para danos morais variaram

\footnotetext{
$\checkmark \nabla \nabla$

1 Universidade de São Paulo, Faculdade de Odontologia, Departamento de Odontologia Social. Av. Prof. Lineu Prestes 2227, 05508-000, São Paulo, SP, Brasil. Correspondence to: GC Rosa. E-mail: <gabrielacrosa@usp.br>.

${ }^{2}$ Associação Brasileira de Odontologia - Seção Rio Grande do Sul (ABORS), Departamento de Odontologia Legal. Porto Alegre, RS, Brasil.

3 Universidade Estadual de Campinas, Faculdade de Odontologia, Departamento de Morfologia, Área de Anatomia. Piracicaba, SP, Brasil.

$\checkmark v \nabla$

How to cite this article

Rosa GC, Baldasso RP, Fernandes MM, Delwing F, Oliveira RN. Trends in the valuation of injury involving the face: an analysis on trial in Rio Grande do Sul, Brazil. RGO, Rev Gaúch Odontol. 2020;68:e20200010. http://dx.doi.org/10.1590/1981-863720200001020180050
} 
entre 1.500,00 e 20.340,00 reais, para dano estético de 2.000,00 e 20.000,00. Conclusão: A análise das jurisprudências nos permite verificar a tendência de necessidade e valorização do perito cirurgião-dentista para quantificação de danos envolvendo o complexo bucomaxilofacial.

Termos de indexação: Estética. Odontologia legal. Legislação \& jurisprudência.

\section{INTRODUCTION}

Trauma in the head and neck is often discussed in literature due to its high incidence in Brazil. The number of cases occurred in the bucomaxillofacial region was three times bigger in a period of 4 years. This is because that is a very exposed and usually unprotected region $[1,2]$.

The stomatognathic system comprises the dental arches, maxilla, mandible, temporomandibular joint (TMJ), skull bones, hyoid bone and neuromuscular structures [3].

Injury in these regions may considerably change people's quality of life, whether as to the speech, chewing, phonetics, in addition to appearance-related dissatisfaction and decreased self-esteem. The relationship between the body image and the well being is very strong, and any change may affect the individual $[4,5]$.

In the last four decades, there was a significant increase in automobile accidents and urban violence. As a consequence, face injuries are notably frequent in emergency centers [3]. Males tend to present higher rates of face injuries, as the main causes are traffic accidents, falls and violence, which have jointly increased by $50 \%$ in in the last years [6]. Proportionally, an increase was observed in the number of cases aimed at compensation for damages [7].

Brazilian Civil Code points out that all damage caused as a result of an illegal act must be repaired, whether monetary or not. When established a civil proceeding, the reimbursement thereto must be proportional to the loss caused to the victim, which may be either physical or psychological $[8,9]$.

To assess this amount, it is necessary to evaluate the bodily injury for identifying the consequences caused to the victim. This assessment of damage is made through a detailed analysis run by an expert who forwards the information to the authority entitled to determine the indemnity quantum, whether through moral, aesthetic and material damages [10].

This bodily injury evaluation lacks approach standardization. It is extremely important to bring the methods together in situations where damage valuation is required so that similar cases have similar and fair indemnities [11].

Although the Law governing the Odontology in Brazil already covers the civilian expert practices of a dental surgeon, the consolidation of these standards for procedures before the Dentistry Councils establishes such practice in civil forums as the competence of specialists in Legal Dentistry, with the expert practice under the civil sphere governed by the Civil Procedural Code, or Law 13,105, of March 16, $2015[12,13,14]$.

Considering the increased number of procedures over the last years, it is important to investigate more deeply the case law. This work aims to analyze the characteristics of case law related to civil proceedings involving the valuation of damages caused by trauma in the stomatognathic system.

\section{METHODS}

This observational study is a retrospective analysis of secondary data, which are public domain, of the case law of the State Court of Rio Grande do Sul (TJRS), from January 2008 to December 2016, as regards to trauma in the bucomaxillofacial.

The survey was carried out through TJRS website (https://www.jusbrasil.com.br), and consultation was done through option "case law search". In the search field, the following keywords were used: aggression, bucco-facial injury, traffic accident, permanent disability and dental fracture. Furthermore, the research was restricted through a system resource by which the item "entire content" was selected and the court of Rio Grande do Sul was selected in the court field.

The sample consisted of cases related to traffic accidents, falls or aggressions affecting the face. As a criterion for inclusion, the cases must have been tried in second instance and have the full text of the judgment available on the website.

In order to comply with ethical principles, this study was sent to FOP/UNICAMP ethics committee for researches and approved under protocol number 010/2010. 


\section{RESULTS}

After analyzing the case law, the sample comprised of 54 judgments held from 2008 to 2016 . The year with greater occurrence of proceedings was 2016 with $20.37 \%$ $(n=11)$, followed by 2015 with $16.6 \%(n=9), 2012$ with
$14.8 \%(n=8), 2013$ with $12.9 \%(n=7), 2014$ and 2010 with $9.25 \%(n=5)$, and the remaining years with less than 9\% (figure 1).

The most prominent city was the capital of Rio Grande do Sul, Porto Alegre, with $22.2 \%$. Followed by

$\mathbf{N}^{\circ}$

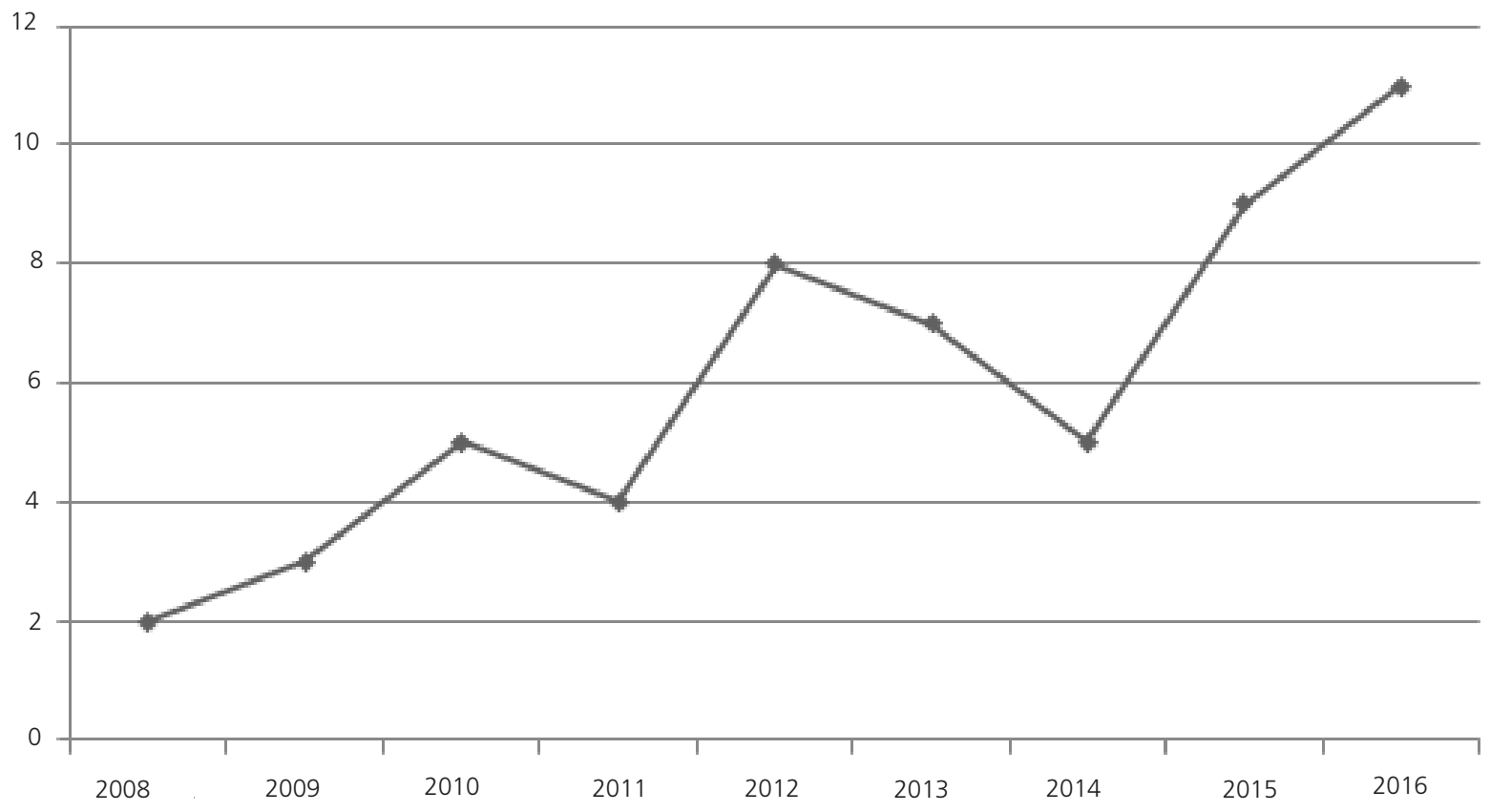

Figure 1. Number of proceedings per year.

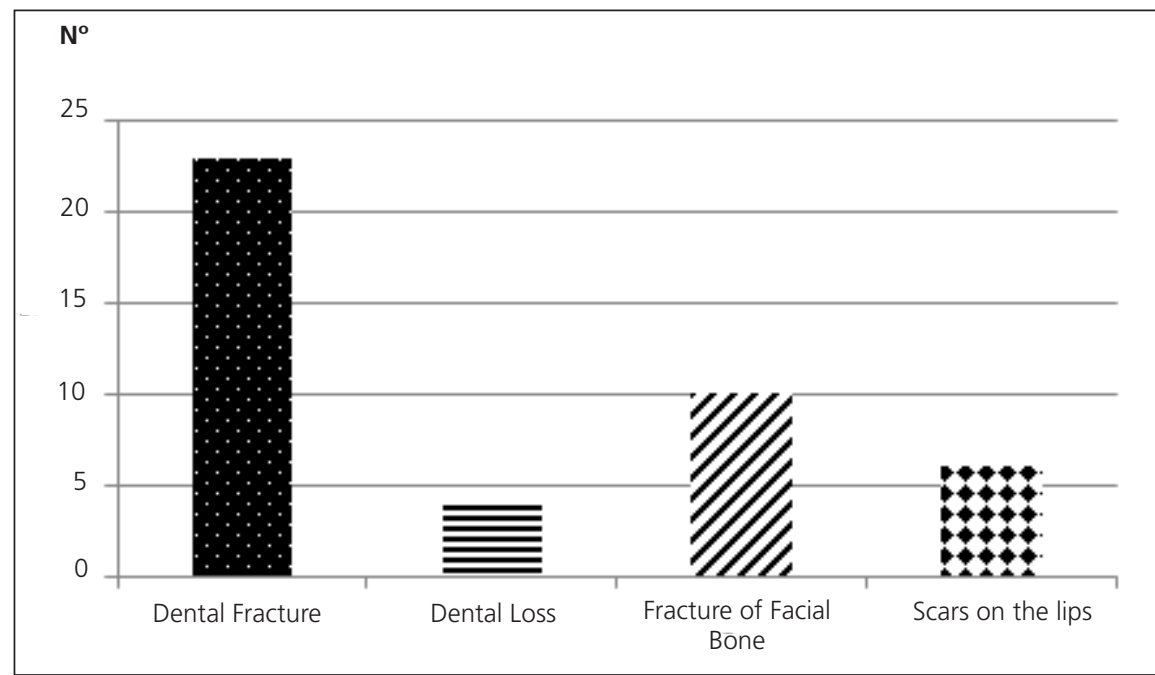

Figure 2. Type of injuries. 
Table 1. Description of the number of indemnities for material, moral and aesthetic damages and their minimum and maximum values.

\begin{tabular}{lcccccr}
\hline & $N^{\circ}$ & Percentage (\%) & Minimum value & Maximum value & Average & Median \\
\hline Material Damages & 31 & 72 & 500.00 & $50,959.00$ & $5,340.00$ & $2,009.00$ \\
Moral Damages & 37 & 86 & $1,500.00$ & $20,340.00$ & $12,639.00$ & $10,000.00$ \\
Aesthetic Damages & 10 & 23.2 & $2,000.00$ & $20,000.00$ & $10,060.00$ & $8,300.00$ \\
\hline
\end{tabular}

Caxias do Sul with 11.1\%; Estância Velha with 5.5\%; Vacaria, Passo Fundo, Lajeado, Erechim and Soledade with $3.7 \%$, and finally, 23 cities in the state corresponding, each, to $1.8 \%$ of the sample.

The most frequent cause of trauma in the case law was aggression, with 32 trials, equivalent to $59.2 \%$, followed by traffic accidents with $31.4 \%(n=17)$ and fall with $9,2 \%(n=5)$.

As regards the plaintiffs, $86 \%$ are male and $14 \%$ female. While respondents are 58\% male, 9.3\% female, and $30.23 \%$ legal entities.

Concerning the type of injury, $53.49 \%(n=23)$ are fracture of one or more teeth, $23.25 \%(n=10)$ are dental losses, $13.95 \%(n=6)$ corresponds to fracture of facial bones and $9,3 \%$ to scars on the lips $(n=4)$ (figure 2 ).

Among the 43 cases selected, 31 were convicted to pay material damages, 37 would have to indemnify the respondents for moral damages and only 10 were ordered to pay aesthetic damages (table1).

As regards the indemnity of the sentence and the judgment, $88.37 \%$ of the cases upheld the sentences, and only $11.63 \%$ obtained reductions in the amounts payable.

\section{DISCUSSION}

An expert performs the assessment of the bodily harm aimed at determining the injury suffered by the victim. This demand has increased due to the large number of traumas involving the face and its adjacent structures $[5,15]$

As a result, the most prominent city was the capital of the State, Porto Alegre, followed by Caxias do Sul. This can be explained by the greater number of inhabitants of the capital, in addition to higher violence rates and more highway.

According to the study performed by Cavalcante et al. [15], conducted in the hospital for emergencies and trauma Senador Humberto Lucena, in the state of Paraíba, the most frequent etiology for facial trauma was physical aggression with $35.7 \%$ of cases analyzed, corroborating with the data found in jurisprudence. However, contrary to this research, in the state of São Paulo the most recurrent etiology found was traffic accident, corresponding to $48,8 \%$ of the cases, followed by falls, with $26,5 \%$ and, finally, aggressions, with 23,5\% [16].

As regards gender, whether as plaintiffs or as defendants, males were more recurrent. This can be explained by the fact that men are more likely to cause traumas, as they tend to more actively engage risky events, such as fights, extreme activities reckless driving [17].

The most prevailing type of injury was dental fracture followed by loss of the tooth. According to Verçosa [5], the smile is the essence of human communication. Once the appearance-related satisfaction is lost, damages can be generated, both of physical and psychosocial nature. All damage caused, whether monetary or not, must be repaired $[9,18]$.

Aesthetic damages are considered non-monetary compensation. The main problem of the calculation of said damages lays on the fact that to assess a damage cause to a third-party is a subjective task, which depends on the expert's senses, especially on touch and vision [19]. Given the subjectivity, many experts and magistrates fail to assess the magnitude of such damage to the victim's life.

This can be observed if we consider that only 10 out of 43 cases obtained compensation for aesthetic damages, while in 37 cases moral damages payment was ordered. The lowest number of compensation for aesthetic damages was found in study conducted by Picoli [20]. where only 5 out of the 319 cases obtained compensation, as Bouchardet et al. [21]. in Minas Gerais and the study carried out in Rio Grande do Sul [19], where only 1 and 3 cases had to pay aesthetic damages, respectively.

In line with the results found in study carried out in Minas Gerais [21] and Picoli [20], an inclination towards the compensation for moral damages is clear, thus not covering the reparation of the damage actually suffered. 
This suggests a tendency for the processes to assume a commercial nature.

We further emphasize the great discrepancy between the minimum and maximum values of indemnities. Based on the results obtained in this study, moral damages range from $R \$ 1,500$ to $R \$ 20,340$, similarly to the results obtained in the studies by Bouchardet et al. [21] carried out in Minas Gerais, Fernandes et al. [19], carried out Rio Grande do Sul, Castro et al. [7] carried out in the centralwest region and Picoli [20] carried out throughout the regions of brazil. These researches have found values ranging from $R \$ 1,000$ up to $R \$ 70,000$, with no amount assigned up to $R \$ 30,600$ and from $R \$ 2000$ to $R \$ 25,000$, respectively.

The same is observed in the compensation values for aesthetic damages, for which the variation in this study was from $R \$ 2,000$ to $R \$ 20,000$, confirming the findings of the study carried out in Rio Grande do Sul [19], whose results presented oscillation of compensation from $R \$ 5,100$ to $\$ 23,250$. The study conducted by Picoli [20] found values of up to $R \$ 50,000$.

The main limitation of the present study is to have access only to sentence and the judgment. For a more in-depth analysis it would be ideal to have an overview of the report content, however, this wide gap between the maximum and minimum values suggests the lack of objectivity and a pattern for the damage calculation process in many Brazilian regions [22,23].

In this type of evaluations, one of the biggest challenges for dental experts is the amount of details in the expert report and the correct methodology to be used, which contributes to such discrepancies in the amounts. In this sense, we highlight the importance of making a report consistent with the situation, which must be the main evidence used by the magistrate [24].

In Brazil, the specific evaluation of the damage presents further relevant discrepancies. It is necessary to standardize the damage calculation methods and the language in order to obtain fairer compensation $[10,25]$.

According to article 944 of the Brazilian Civil Statute [26], the purpose of the valuation is the full repair. In this sense, the indemnity must be proportionate to the damage. The use of tables in these cases can be of great relevance, as it is a tool that allows unifying criteria in order to avoid discrepancies in values of similar cases. However, to successfully fulfill their function, the current tables need more scientific basis, therefore we emphasize the importance of studies directed to the creation or adequacy of such tools [5].

\section{CONCLUSION}

Face trauma is more prevalence in males both as plaintiff and as defendant, the most frequent etiology was physical aggression and the most recurrent type of injury was dental fracture, and the tendency to compensation for moral damages was clear, compared to a lower incidence of aesthetic damages, because of this, it allows us to find an inclination towards the need and appreciation of the surgeon-dentist expert for quantifying damages involving the buccomaxillofacial complex.

\section{Collaborators}

GC ROSA, worked on the conception, design, collection, analysis and writing of the article. RP BALDASSO, worked in the interpretation of the data. MM FERNANDES, worked in the conception, methodology, and critical review of the article. F DELWING, worked on the conception, and critical review of the article. RN OLIVEIRA, worked on the critical review of the article.

\section{REFERENCES}

1. Scannavino FLF, Santos FS, Novo Neto JP, Novo LPereira. Análise epidemiológica dos traumas bucomaxilofaciais deum serviço de emergência. Rev Cir Traumatol Buco-Maxilo-Fac. 2013;13(4): 95-100.

2. Roselini LMR, Bregagnolo LA, Pardinho MABS, Chiaperini A, Bérgamo AL, Santi LN, et al. Danos buco-maxilo-faciais em homens da região de Ribeirão Preto (SP) entre 1998 a 2002. Odontol, Ciência e Saúde. 2009;10(2):71-77.

3. Bouchardet FCH, Teixeira AS, Carvalho CM, Santos WB, Vieira DNP, Silva RF. Necessidade de avaliação das lesões dentais em casos de invalidez permanente por acidente. RFO, Passo Fundo. 2013;18(3):381-385. https://doi.org/10.5335/rfo.v18 i3.3665

4. Souza AM. Verificação do grau de severidade em alterações faciais segundo a análise de quatro grupos profissionais [dissertação]. São Paulo: FOUSP; 2006.

5. Verçosa CB, Santos CE, Shimokawa CAK, Vieira GF, Melani $\mathrm{RFH}$. Verificação do grau de severidade estética em perdas dentárias anteriores superiores. Rev Assoc Paul Cir Dent. 2012;66(3):200-5.

6. Camarini ET, Pavan, AJ, Iwaki Filho L, Barbosa CEB. Estudo epidemiológico dos traumatismos bucomaxilofaciais na 
região metropolitana de Maringá-PR entre os anos de 1997 a 2003. Rev Cir Traumatol Buco-Maxilo-Fac. 2004;4(2):131-135.

7. Castro ACC, Franco A, Silva RF, Portilho CDM, Oliveira HCM. Prevalence and content of legal suits founded on dental malpractice in the courts of midwest brazil. RBOL. 2015;2(1):46-52. http://dx.doi.org/10.21117/rbol.v2i1.20

8. Brasil. Código civil. Vade Mecum Saraiva. São Paulo: Saraiva; 2014.

9. Paula FJ, Motta MV, Bersácola RN, Muñoz DR, Silva M. Panorama das ações de responsabilidade civil contra o odontólogo nos tribunais do Brasil. Rev Paul Odontol. 2010;32(4): 22-28.

10. Bouchardet FHC, Criado del Río MT. Propuesta de una guía para la valoración médico-legal de la alteración estética: daño estético/deformidad. Rev Port Dano Corporal. 2010;21:119-130.

11. Silva BR, Santos WB. Antecedentes históricos. In: Silva BR, Carvalho CM, Bouchardet FCH, Silva WFM, Santos WB. Avaliação do dano corporal pós-traumático: metodologia europeia aplicada ao contexto brasileiro. Belo Horizonte: Mazza; 2010. p. 23-28.

12. Brasil. Lei ordinária n. 5.081 de 24 de agosto de 1966. Regulamenta o exercício da Odontologia no Brasil. Diário Oficial da União. Brasília, 1966.

13. Brasil. Lei ordinária n. 13.105, de 16 de março de 2015. Institui o Código de Processo Civil. Diário Oficial da União. Brasília, 2015; 17 out 17.

14. Conselho Federal de Odontologia. Consolidação das Normas para procedimentos nos Conselhos de Odontologia, aprovada pela Resolução CFO-63/2005, atualizada em 18 de maio de 2005. Diário Oficial da União 2005; 19 abr.

15. Cavalcante AL, Lima IJD, Leite RB. Perfil dos Pacientes com fraturas maxilo-faciais atendidos em um hospital de emergência e trauma, João Pessoa, PB, Brasil. Pesq Bras Odontoped Clin Integr. 2009;9(3):339-345. http://dx.doi.org/ 10.4034/1519.0501.2009.0093.0015

16. Andrade Filho E, Fadul Junior R, Azevedo RAA, Rocha MAD, Santos RA, Toledo SR, et al. Fraturas de mandíbula: análise de 166 casos. Rev Ass Med Brasil. 2000;46(3):272-6272.

17. Lopes ALC, Rangel CLG, Paiva KRG, Camara THQ, Ferreira MAF. Prevalência dos traumas buco-faciais em pacientes atendidos no Hospital Walfredo Gurgel (Natal- Rio Grande do Norte). Rev Cir Traumatol Buco-Maxilo-Fac. 2011;11(2):123-130.

18. Verçosa CB, Togna GRD, Dias PEM, Melani RFH. Tabelas na quantificação do dano odontológico: relato de caso. RBOL. 2014;1(1):4-11. http://dx.doi.org/10.21117/rbol.v1i1.2

19. Fernandes MM, Bouchardet FCH, Tavares GSV, Daruge Junior E, Paranhos LR. Aspectos odontolegais relacionados ao dano estético nos processos julgados pelo TJ/RS. Odonto. 2012;20(40):7-12. http://dx.doi.org/10.15603/2176-1000/ odonto.v20n40p7-12

20. Picoli FF. Análise das jurisprudências sobre alegado erro odontológico em tratamentos ortodônticos no brasil [dissertação]. Goiânia: Universidade Federal de Goiás; 2017.

21. Bouchardet FCH, Vieira SLG, Miranda GE, Fernandes MM, Vieira DNP, Silva, Rhonan F. Valoração do dano estético nos acórdãos do Tribunal de Justiça de Minas Gerais. Rev Odontol Bras Central. 2013;22(63):

22. Verçosa, C.B., Melani, R.F., Tabelas como referência para estabelecimento do valor indenizatório dos danos odontológicos. Rev Assoc Paul Cir dente. 2011;65(3):170-9

23. Rosa FM, Fernandes MM, Júnior, ED. Danos materiais e morais em processos envolvendo cirurgiões-dentistas no estado de São Paulo. RFO, Passo Fundo. 2012; 17(1): 26-30. https://doi. org/10.5335/rfo.v17i1.2537

24. Zanin, AA, Strapasson, RAP, Melani, RFH. Levantamento Jurisprudencial: provas em processos de responsabilidade civil odontológica. Rev Assoc Paul Cir Dent. 2015; 69(2): 120-7.

25. Fernandes MM, Cobo Plana JA, Bouchardet FCH, MichelCrosato E, Oliveira RN. Validação de instrumento para análise do dano estético no Brasil. Saúde Debate. 2016;40(108):118130. https://doi.org/10.1590/0103-1104-20161080010

26. Brasil. Lei ordinária n. 10.1406, de 10 de janeiro de 2002. Institui o Código Civil. Diário Oficial da União. Brasília [citado 2019 Fev 11]. Disponível em: <http://www.jusbrasil.com. br/topicos/10676887/artigo-944-da-lei-n-10406-de-10-dejaneiro-de-2002>. 